\title{
TOBACCO AND TOBACCO PRODUCTION IN THE REPUBLIC NORTH MACEDONIA CONTINUE TO HAVE THE PRIMACY OF AN INDUSTRIAL CROP WITHOUT AN ALTERNATIVE
}

\author{
Associate Professor Dr. Silvanapashovska And Assistant Professor Dr.Natashazdraveska \\ University St. Klimentohridski - Bitola, Scientific Tobacco Institute - Prilep,Republic Of North Macedonia
}

https://doi.org/10.35410/IJAEB.2020.5591

\begin{abstract}
Tobacco, as a crop, has a special position in the structure of agricultural production and the structure of export, with a particular importance from an economic and social aspect, primarily in specific regions where it represents an important source of finance and livelihood of the population. The emergence of tobacco in Macedonia is closely related to its spread in the Balkan Peninsula, as one of the fundamental products that were important for trade at the time. For this particular reason the production of tobacco in the Republic of North Macedonia has more than historical importance and it is one of the basic traditional activities of every agricultural family in the regions where conditions for its cultivation exist.
\end{abstract}

It is particularly important to mention that this plant is grown in conditions where any other crop cannot replace tobacco in terms of its cultivation in soils with lower quality, where it provides adequate yield and quality, and thus provides a decent income. These are rural areas in the country where a large part of the rural population lives and the cultivation of tobacco dominates within the agricultural activities. It is a matter of an oriental tobacco type, which is closely related to the Macedonian region, which disposes of favorable natural, agro-ecological conditions for its production.

Namely, the territory of the Republic of North Macedonia has appropriate soil and climatic characteristics for growing this tobacco type (however some other tobacco types can be grown as well), of certain varieties that are unique in terms of the expressed specific aroma and the high quality of raw material, which is recognizable in the world. Therefore, the tobacco production in the Republic of North Macedonia has a particular economic significance for the country

Keywords: Tobacco Production, Subsidies, Revenues, Alternatives, Perspectives.

\section{INTRODUCTION}

How profitable is tobacco production and is there an alternative to it, is a question for the numerous producers not only in the region of Prilep, but also countrywide. More than 30.000 Macedonian families provide their sustenance from this industrial production, whereby more than half of the production takes place in the Pelagonija region, and a major part of the tobacco is produced in the Prilep-Dolneni region. According to the latest indicators, of the average production of 25.000 tons in the country, more than 17.000 tons are produced in the Pelagonija 
region, and more than 10.000 thousand tons in the Prilep region. Specifically, about 7.000 tons of tobacco are produced in the area of Dolneni, and the remaining part is in the Prilep region. Tobacco production maintains an enviable quantitative level, and in recent years a high quality level as well. Considering the current subsidies of 80 denars for first class, 70 denars for second class and 60 denars for third class and other classes, tobacco production is indeed profitable for tobacco growers, which provides them livelihood, but also additional profit.

In the past decade, the state subsidies have providedpure profit to tobacco growers. However, due to varying interest of the new generations, who do not like too much physical, agricultural work, and rather prefer "physical" work abroad because of higher earnings, the production slowly moves to the rural areas. In this regard, it is necessary to mention the fact that the production of tobacco as an agricultural crop requires a significant engagement of all family members for several months, which reduces the interest among younger generations, especially in urban areas. However, despite this fact, the experience and years-long tradition in the process of tobacco production shows that areas where tobacco has been cultivated for many years, can hardly be economically viable if planted with other crops as a replacement of tobacco. These claims are supported by the fact that tobacco is a strategic crop that annually brings more than 100 million Euros of income to the country and more than 30.000 families provide their sustenance thanks to tobacco production. Therefore, as long as the tobacco production is successful, as long as it provides livelihood for $\mathbf{3 0 . 0 0 0 ~ f a m i l i e s ~ f r o m ~ t h e ~ c o u n t r y , ~ a s ~ l o n g ~ a s ~ t h e r e ~}$ is market demand and buyers are on the ground in order to collect as larger quantities of tobacco as possible in the country, tobacco has no other alternative. With the current production and the state support with subsidies, the tobacco production secures its future. For the time being, projects and "experiments" for new agricultural crops remain as they are -only projects and experiments. Tobacco stays in the fields, mostly in the region of Prilep-Pelagonija, both as a source of livelihood and income with higher expectations in the future.

\section{Subsidies in tobacco production - financial injection and incentive for producers}

For the Republic of Macedonia, tobacco is a strategic export-oriented branch that has a stable and sustainable production. Tobacco is the only crop with guaranteed purchase by the state and guaranteed subsidies that are paid with the new model in the amount of 80 denars per kilogram for first class, 70 denarsper kilogram for second class and 60 denars per kilogram for third class and additional classes. Below is a tabular presentation of the paid subsidies by years, as well as the number of concluded agreements with the producers, the sown areas, the purchased quantity and the average price for the purchased tobacco. 
Table 1. Number of agreements, plantations, purchased tobacco, average reached price in denars per kilogram and paid subsidies in the form of direct payments

\begin{tabular}{|c|c|c|c|c|c|}
\hline Year & $\begin{array}{c}\text { Number of } \\
\text { agreements }\end{array}$ & $\begin{array}{c}\text { Plantation } \\
\text { s } \\
-h a-\end{array}$ & $\begin{array}{c}\text { Purchase } \\
- \text { tons- }\end{array}$ & $\begin{array}{c}\text { Average } \\
\text { priceden/kg }\end{array}$ & Subsidies \\
\hline 1991 & 37543 & 20818 & - & & \\
\hline 1997 & 33000 & 16890 & 25452 & & \\
\hline 1998 & 54661 & 21657 & 20880 & & \\
\hline 1999 & 43622 & 19947 & 32398 & & \\
\hline 2000 & 34254 & 22785 & 28122 & & \\
\hline 2001 & 33906 & 20074 & 20097 & & \\
\hline 2002 & 26971 & 20615 & 22500 & & \\
\hline 2003 & 27343 & 15017 & 23000 & & \\
\hline 2004 & 38493 & 15204 & 19839 & & \\
\hline 2005 & 39028 & 15808 & 23196 & & \\
\hline 2006 & 29230 & 15072 & 23083 & 118,1 & $295.215 .000,00$ \\
\hline 2007 & 29771 & 16870 & 19680 & 140,6 & $488.700 .000,00$ \\
\hline 2008 & 30519 & 17185 & 16280 & 167,4 & $725.670 .000,00$ \\
\hline 2009 & 38710 & 16212 & 23196 & 191,9 & $1.393 .300 .440,00$ \\
\hline 2010 & 40.743 & 18846 & 26393 & 136,6 & $1.583 .580 .000,00$ \\
\hline 2011 & 33.234 & 15.677 & 21024 & 164,8 & $1.261 .440 .000,00$ \\
\hline 2012 & 29.090 & 14.609 & 27.993 & 180,2 & $1.679 .580 .000,00$ \\
\hline 2013 & 42.367 & 19.806 & 30.997 & 152,6 & $1.859 .820 .000,00$ \\
\hline 2014 & 34.445 & 17.757 & 27.578 & 117 & 1.452 .820 .000 .00 \\
\hline 2015 & 28.454 & 16.128 & 24.237 & 185 & $2.154 .695 .000,00$ \\
\hline 2016 & 27.380 & 16.379 & 25.446 & 196,80 & $1.507 .877 .447,00$ \\
\hline 2017 & 29.354 & 14.415 & 23,544 & 217,60 & $1.692 .439 .853,00$ \\
\hline 2018 & 34.104 & 14.802 & 25,200 & 214,26 & \\
\hline 2019 & 32.798 & 13.342 & 26.700 & 222.5 & $1.722 .000 .000,00$ \\
\hline & & & & & $1.814 .250 .000,00$ \\
\hline
\end{tabular}

Source: Chamber of Commerce of the Republic of North Macedonia

The amount of direct payments per kilogram of tobacco in the past period is 60.00 denars $/ \mathrm{kg}$ of unprocessed oriental small-leafed tobacco until the 2016 harvest and in the harvests in 2017 and 2018 an average of 70.00 denars $/ \mathrm{kg}$ were paid (80 denars $/ \mathrm{kg}$ for first class, 70 denars $/ \mathrm{kg}$ for second class and 60 denars $/ \mathrm{kg}$ for third class and other classes). This data is presented in the following table by years: 
Table 2. Share of direct payments for tobacco in the total value per kilogram, 2009-2018 (average purchase price + subsidy)

\begin{tabular}{|l|l|l|l|l|}
\hline Harvest & $\begin{array}{l}\text { Average } \\
\text { purchase price } \\
\text { in denars/kg }\end{array}$ & $\begin{array}{l}\text { Amount of } \\
\text { direct } \\
\text { payments per } \\
\text { kg. }\end{array}$ & $\begin{array}{l}\text { Total value } \\
\text { denars/kg }\end{array}$ & $\begin{array}{l}\text { Share of direct } \\
\text { payments in the } \\
\text { total value in \% }\end{array}$ \\
\hline 2018 & 214,20 & 70,00 & 284,20 & 24,6 \\
\hline 2017 & 217,60 & 70,00 & 287,60 & 24,3 \\
\hline 2016 & 196,80 & 60,00 & 256,80 & 23,4 \\
\hline 2015 & 184,50 & 60,00 & 244,50 & 24,5 \\
\hline 2014 & 117,20 & 60,00 & 177,20 & 33,9 \\
\hline 2013 & 152,20 & 60,00 & 212,20 & 28,3 \\
\hline 2012 & 180,20 & 60,00 & 240,20 & 25,0 \\
\hline 2011 & 164,80 & 60,00 & 224,80 & 26,7 \\
\hline 2010 & 136,70 & 60,00 & 196,70 & 30,5 \\
\hline 2009 & 192,00 & 60,00 & 252,00 & 23,8 \\
\hline $\begin{array}{l}\text { Average } \\
\mathbf{2 0 0 9 - 2 0 1 8}\end{array}$ & $\mathbf{1 7 5 , 6 2}$ & $\mathbf{6 2 , 0 0}$ & $\mathbf{2 3 7 , 6 2}$ & $\mathbf{2 6 , 5}$ \\
\hline S010:
\end{tabular}

Source: Tobacco production strategy for the period $2020-2026$

For the period 2009-2013 the average purchase price is 165.2 denars $/ \mathrm{kg}$, while for the period 2014-2018 it is 186.1 denars $/ \mathrm{kg}$ and it is higher in a relative amount by $12.6 \%$. The period 20092013 is a program period, before the adoption of the National Strategy for Agriculture and Rural Development, while the period 2014-2018 followed after the adoption of the National Strategy for Agriculture and Rural Development.

The share of direct payments in the total value per kilogram of tobacco (period 2009-2018) is an average of $26.5 \%$, within the range from $33.9 \%$ in 2014 up to $23.4 \%$ in 2016.

The variability of the share of direct payments in the total value (purchase price + subsidy) in $\%$ arises from the amount of the average purchase price in terms of harvests.

Table 3. Comparison of the tobacco production, the purchase and the direct payments between the program period of 2009-2013 and the program period of 2014-2018

\begin{tabular}{|l|l|l|l|l|l|}
\hline Program period & $\begin{array}{l}\text { Average } \\
\text { agreed } \\
\text { areas in ha }\end{array}$ & $\begin{array}{l}\text { Average } \\
\text { purchases } \\
\text { quantities in } \\
\text { tons }\end{array}$ & $\begin{array}{l}\text { Average } \\
\text { number of } \\
\text { tobacco } \\
\text { holdings }\end{array}$ & $\begin{array}{l}\text { Average } \\
\text { purchase } \\
\text { prices } \\
\text { denars/kg }\end{array}$ & $\begin{array}{l}\text { Average } \\
\text { direct } \\
\text { payments in } \\
\text { denars/kg }\end{array}$ \\
\hline $2009-2013$ & 16.677 & 25.972 & 35.805 & 165,00 & 60,00 \\
\hline $2014-2018$ & 14.134 & 23.072 & 25.452 & 186,00 & 64,00 \\
\hline absolutedifference & -2.543 & -2.900 & -10.353 & $+21,00$ & $+4,00$ \\
\hline
\end{tabular}


Vol. 5, No. 06; 2020

ISSN: $2456-8643$

\begin{tabular}{|l|l|l|l|l|l|}
\hline $\begin{array}{l}\text { relative amount in } \\
\%\end{array}$ & $-18,0 \%$ & $-12,6 \%$ & $-40,7$ & $+11,3 \%$ & $+6,3 \%$ \\
\hline
\end{tabular}

Source: Tobacco production strategy for the period $2020-2026$

The data in Table 3 shows that in the second programperiod (2014-2018) the agreed areas decreased by $18 \%$, the purchased quantity decreased by $12.6 \%$ and the number of tobacco holdings decreased by $40.7 \%$, and the average purchase price increased by $11.3 \%$, same as the direct payments that increased by $6.3 \%$.

The reduction of the agreed areas and the number of agricultural holdings is essentially due to the increased control with the registers and the information system for recording the tobacco holdings.

The effects of the agricultural policy in the tobacco sector are recorded through the increased support by $6.3 \%$ which together with the increased purchase price represent an increase of $17.6 \%$ of the total income of the tobacco holdings.

\section{What are the effects of WHO's efforts to find an alternative to tobacco?}

The Framework Convention on Tobacco Control (FCTC), more specifically Article 17, strives to gradually replace the tobacco crop with other agricultural crops, as well as to reduce the use of tobacco for the production of cigarettes and convert it, as an opportunity to obtainbio mass and bio fuel. The signatory countries of this agreement, tobacco producers, have been under pressure for a long time in regard to its application. The ten-year discussions on this article did not provide an answer for its considerable implementation, which suggests that it is impossible to realize it. According to the opinion of the farmers - tobacco producers, the imposed article is not adequately efficient, because the decisions about tobacco are made by people who are not responsible for this problematics. Globally at this moment, the alternative replacement of tobacco with other crops is quite dubious and there is no solid alternative with a use value that can be offered to tobacco producers, and which can give them greater security.

It is difficult and unrealistic to form an alternative at a farmer level for the entire tobacco sector worldwide. For tobacco producers, the alternative tobacco solution on a global scale is quite problematic. The alternative crop for tobacco must have a constant, continuous demand, starting from the primary part, throughout the entire reproductive cycle, ending with the marketing (the market). This is particularly important for tobacco growers fromless developed and developing countries. The alternative crop must primarily provide jobs, that is, engagement of labor that is at least approximately the same as the labor engagedfor tobacco crops. Statistically, almost all tobacco types, especially small leafed tobacco, require 2.500 working hours per hectare. More than 30.000.000 farmers are engaged worldwide, which is very important and creates a large reserve for the acceptance of Article 17 of the Framework Convention. Any solution so far in this field, is far from reality. One of the objections of the tobacco producers is that according to this article, they are not given the right to decide on this problematics which refers to their livelihood. Solutions are made and responsibilities are proposed without complying with their needs and fully understanding the problematics. Many of the creators of this article do not have profound knowledge regarding the production process - the reproduction of tobacco, because they are representatives of other scientific fields: healthcare, pharmacy, customs, etc. Basically, 
they cannot understand the dominance and importance of tobacco from a social, economic and political point of view.

The WHO has developed a scheme for the alternative use of tobacco crops for the application of Article 17 of the Framework Convention. It strives to achieve the following:

- To limit the areas covered by tobacco;

- Restriction of annual tobacco production;

- Restriction of any kind of assistance of technical and technological nature;

- Prohibition of farmers to commence new tobacco production; and

- Restrictions on public and private funds intended to support tobacco production.

These extreme efforts of the WHO have been rejected and active involvement of farmers in making appropriate decisions is required. From the previous discussions regarding this article, their absence has not been explained, i.e. the ignoring of farmers and the tobacco industry as a whole.

In some countries, certain endeavors have been undertaken in regard to this article, to replace the tobacco crop with another, alternative crop. However, the taken measures thereof in 2005 proved to be unsuccessful. The Brazilian government has prepared a project for 80.000 farmers, however the results do not correspond to the real situation -the production has increased. The reason is that it was a state project, instead of involving the private sector. There are no available data regarding the current harvest after this program. A similar program in 2009 for 6.000 farmers was adopted in Malawi. According to the data from 2014, the number of farmers under this program reduced to 1.600 , which means that producers abandoned tobacco production, however did not accept the alternative. The reason again is that this project is regulated by the country that purchases the production, which means that there is no real market led by the real sector. As such, these programs for an alternative to tobacco have no future.

The non-fulfillment of the efforts of the WHOfor alternative replacement of tobacco production with other crops, on a global level, is evident in the following table:

Table 4. Representative countries in the world, tobacco producers

\begin{tabular}{|l|r|r|l|}
\hline $\begin{array}{c}\text { Representative } \\
\text { countries, tobacco } \\
\text { producers }\end{array}$ & $\begin{array}{c}\text { Production in } 2008 \text { in } \\
\text { "tons" }\end{array}$ & $\begin{array}{c}\text { Production in } 2013 \text { in } \\
\text { "tons" }\end{array}$ & $\begin{array}{l}\text { Production in } 2018 \text { in } \\
\text { "tons" }\end{array}$ \\
\hline China & 2.839 .725 & 3.150 .000 & 2.242 .177 \\
Brazil & 859.058 & 850.000 & 762.266 \\
India & 490.000 & 830.000 & 749.907 \\
USA & 361.000 & 345.000 & 241.870 \\
\hline
\end{tabular}


Vol. 5, No. 06; 2020

ISSN: $2456-8643$

\begin{tabular}{|l|r|r|l|}
\hline Argentina & 157.786 & 115.000 & 104.093 \\
Indonesia & 169.668 & 260.000 & 181.095 \\
Malawi & 160.228 & 132.800 & 95.356 \\
Italy & 123.281 & 49.200 & 59.299 \\
Pakistan & 107.768 & 108.307 & 106.727 \\
Turkey & 93.403 & 90.000 & 80.200 \\
Zimbabwe & 81.952 & 150.000 & 132.200 \\
Thailand & 67.588 & 72.000 & 67.230 \\
Mozambique & 64.342 & 56.000 & 93.659 \\
South Korea & 74.469 & 80.000 & 26.175 \\
Tanzania & 50.800 & 86.360 & 107.009 \\
Laos & 31.103 & 40.600 & 54.005 \\
Zambia & 64.066 & 62.000 & 115.950 \\
Canada & 47.162 & 15.145 & 23.105 \\
Bulgaria & 42.161 & 34.000 & 8.640 \\
Poland & 41.200 & 32.000 & 33.190 \\
Greece & 20.500 & 24.000 & 22.730 \\
Romania & 2.360 & 1.357 & 1.259 \\
& & & \\
\hline \multicolumn{1}{|c|}{ Total production: } & 5.965 .628 & 6.583 .357 & \\
\hline \multicolumn{1}{|c|}{} & & & \\
\hline
\end{tabular}

Source: FAOSTAT,2008-2013-2018

Most deviations in the production of raw tobacco in some countries are a result of the influence of natural conditions - droughts, floods, tobacco diseases, rather than being a result of Article 17 of the Framework Convention on Tobacco Control. This means that despite all efforts to find an alternative to tobacco, in the foreseeable future this is unrealistic and unprofitable both for the producers, as well as for the countries where tobacco production is present. 


\section{CONCLUSION}

Macedonian oriental tobacco, due to its high quality, is highly valued on the international market and together with the tobacco products, it represents a significant export product. Today, more than $99 \%$ of the total tobacco production is oriented towards the requirements of the multinational companies that provide placement of fermented tobacco on foreign markets through their registered companies for purchase of raw tobacco.

The primary production of oriental small-leafed aromatic tobacco has great economic and social significance for the Republic of Macedonia, because the country is a traditional producer of this type of tobacco.

Our country does not accept a methodology for reducing tobacco production because it is contrary to the possibility of providing a livelihood for producers who would find it difficult to replace tobacco with another crop. Thereby, one should consider climatic conditions and the economic effect. In the regions where tobacco is grown, there are no climatic conditions for other crops because these are dry places. In regard to the economic effect, a new crop is acceptable only if is a profitable replacement, i.e. it provides livelihood for the producers, which is unlikely for now.

Macedonia is positioned on the $30^{\text {th }}$ place in terms of the quantity of produced tobacco in the world, as well as on the $15^{\text {th }}$ place in terms of the value of the conducted export of tobacco worldwide. The World Health Organization is making efforts to reduce the areascovered by tobacco in the world in general, and not just the areas with oriental tobacco, however thishas been successful only in developed EU member states, while in other parts of the world it is not the case. Tobacco production in such countries is maintained at a stable level. Such is the case of Macedonia where the tobacco cropdoesn't have a suitable alternative so far.

\section{REFERENCE}

State Statistical Office of the Republic of North Macedonia

Ministry of Agriculture, Forestry and Water Economy of the Republic of North Macedonia Agency for Financial Support of Agriculture

National Strategy for Agriculture and Rural Development for the Period 2014-2020

FAOSTAT (Food and Agriculture Organization) - database 2020 